\title{
TECHNICAL TALENT AND TECHNICAL CREATIVITY IN LOWER SECONDARY SCHOOL STUDENTS
}

\author{
Andrej Šafhalter \\ Lower Secondary School Anice Černejeve Makole, Slovenia \\ E-mail: andrej.safhalter@os-makole.si \\ Dragica Pešaković \\ Lower Secondary School Destrnik-Trnovska vas, Slovenia \\ E-mail: dragica.pesakovic@guest.arnes.si
}

\begin{abstract}
Technical subjects should include creative activities in order to foster the development of technical creativity in talented students. Talent should be regarded as a potential or a characteristic, which a certain student possesses. Creativity can be described as an activity through which such talent shows.

The research on the correlation between technical talent and technical creativity included 109 students aged 11 to 15 years, in two Slovenian lower secondary schools. Students were tested by two modified tests on technical creativity and technical talent.

The results show that a positive correlation between technical talent and technical creativity exists. It depends on the gender, age and closing assessment of the student. Females displayed a higher level of technical creativity in comparison to males; however, the males achieved higher scores in the technical talent test. The higher the closing assessment and the age of the students, the higher was the level of their technical talent and technical creativity.
\end{abstract}

Key words: basic education, technical talent, technical creativity, technique and technology.

\section{Introduction}

Gifted students need something, which is impossible to offer at school because of the program. This is the development of creativity. Talent is dealt as a potential, characteristic that a child has, and creativity as activity that this talent is being shown through. So the creativity will mean the activity, through which a certain talent can be expressed. Child's talent will be rarely shown by itself, even less if the environment in which the child is being raised, doesn't offer enough encouragement, motivation, challenges, psychological security.

There were several researches made on the field of creativity in the past, since the specialists from different fields are trying for quite some time to determine its basic features (Craft, 2006), to expose different incentive and counterproductive factors at the development of creativity (Craft, Jeffrey \& Liebling, 2001; Craft, 2006) or to determine its domain on individual fields (Leach, 2001). The basic orientation of research of creativity has been its setting in the context of socially-psychological frame, which organized way of teaching comprises also at the development of individual's creativity. Pečjak (1987) emphasizes that the basic point of view at studying creativity is resourcefulness and originality. Creative answer is always urgent and original, which means that it must give something new, peculiar, rare and also inimitable. 
Andrej ŠAFHALTER, Dragica PEŠAKOVIĆ. Technical talent and technical creativity in lower secondary school students

PROBLEMS

OF EDUCATION

IN THE $21^{\text {st }}$ CENTURY

Volume 65,2015

Many people are caught in rigid manners of thinking. Solutions that they reach are such that they don't notice others, better, or more original. One of the factors, which influences rigidity of opinion, are experiences. In the tests of creative thinking, the conditions must ensure that thinking is divergent and that more solutions or answers are possible. Such test is, for example, the Hargreaves's test of unfinished pictures, the test of addresses of pictures or stories, the test of visible symbols, the test of stories about pictures etc. He is convinced that an individual is limited with certain frames also in everyday life. Kvaščev (Jurman, 2004) suggests four ways of measuring creativity: with tests of creativity, with the help of individual's personality characteristics, with the assessment of individual's creativity and with the assessment of the product.

The test of creativity is characterized by logic, which is the opposite to the logic of intelligence tests, where there is only one solution or response and no possibility of disconformism in thought. Guilford (Jaušovec, 1987) was the one who stopped the tradition of intelligence tests when he divided thinking on convergent and divergent. First, there is the expression at rescuing of closed problems, which are allowing only one solution, the other is reflected in resolving outstanding problems and they are allowing more possible solutions. Guilford (1971) made completely new tests for measuring divergent abilities which comprise factors of divergent thinking. He discovered three large groups of factor's dimensions with factor analyses of divergent thinking: fluency, flexibility and originality, and also two special, elaboration and ability of detecting problems. Based on indicators of creativity, some personal characteristics which are typical for more creative individuals have been exposed in the past (Claxton, Edwards \& Scale-Constantinou, 2006). Claxton (2006) emphasizes six of them, Guilford (1977) together with Lowenfeld (1964) formed eight indicators, which would help with recognizing the presence and level of creativity of an individual (Supek, 1987), namely: sensitivity for problems, receptivity, flexibility, originality, ability to analyze and to abstract, ability of a modification (redefinition), synthesis and coherent organization. Torrance (1974, in Jurman 2004, Pečjak 1987, Jaušovec 1987) saved this problem with the help of questions below that refer to different points of view of creative thinking:

- Who has the most ideas in the class? (fluency),

- Who has original and unusual ideas in the class? (originality),

- Who is the first who finds out a new solution, if situation changes suddenly? (flexibility),

- Who is the one who forwards most detail solution next to a certain problem? (elaboration).

In the field of technique and technology, the definition that is derived from individual's achievement and which it tries to determine as something that is new, is satisfying. Everybody who solved a certain problem in a way that they didn't evoke solution from memory, but made the solution for this newly, is creative (Jaušovec, 1987). Students at the class are realizing how natural legalities are being used in technique and technology and, therefore, they are discovering and meeting simple technical and technological problems and they search, with the use of simple tools they are looking for the ways to solve them. They are creatively connecting natural and technical knowledge with practice. Technique and Technology is a subject that effectuates symbolic level in reality. Students have a possibility to develop their abilities for searching and formatting new solutions, creativity and for deciding for them, over making the objects and constructions (Fakin, Kocijančič, Hostnik \& Florjančič, 2011). Just like for creativity, there isn't only one definition of talent, but there is possible to come across different arguments.

When we have to deal with the word gifted child, we can talk about potential, capability (Galbraith, 1992, in Pregl, 2009). »Gifted or talented are those children and adolescents who have shown on preschool rate, in primary or secondary school, high achievements or potentials on intellectual, creative, specific academic, management or artistic field and the ones who need 
besides regular school program also especially transformed programs and activities.« (Travers etc., 1993, in Pregl, 2009).

"Gifted children are those who are surpassing comparative group of the same aged children within a certain look" (Žagar, 2001, in Pregl, 2009). Talent belongs, just like intelligence and creativity, to mind abilities. Students with general talent can achieve exceptional achievements on several fields at the same time, but students who are specifically talented (partly talented) are mostly achieving exceptional achievements only on a certain field (Pregl, 2009). The known definitions of talent are: generally intellectual, didactic, creative, managemental, technical, physical-locomotor, musical, artistic, literary and dramatic field (Bezić, 2008).

A student who is talented on technical field, knows how to draw a plan, to make a product after this plan, he is skilled, persistent and accurate at putting apart, putting together or repairing mechanical or others machines. He is very good at activities, connected with constructions of different objects, and skilled at the use of tools and gadgets.

The concept of talent has always been used in educational system, but it isn't possible to speak about common definition of this concept. In general we know that talent is always reflected in a creative product. Canadian author Gagne (Jurman, 2004) determines talent as explicitly above-average development of one or more abilities, meanwhile, talent is more of an expression of above-average on one or more fields of human activity. Personality characteristics which we find in the group of talented are referring to different fields: mental-epistemic, didactic-productivity, motivational, social-emotional.

The need for development of creativity is being shown in the need of students, who are trying to combine preliminary connected concepts, ideas or experiences to a new construct or idea. The creativity is being shown through the personality of a creative student, through a creative process (preparation, incubation, illumination, verification, implementation) and through a creative product. Creative students differ from others for their inventiveness, wittiness, they ask unusual questions, they are unorthodox, they are tilted to take chances and they search for different possible solutions. Right cerebral hemisphere is prevailing at their thinking. The stimulation of internal motivation is increasing their creativity, but on the contrary, stimulation of outside motivation is decreasing creativity.

The aim of the research was to find out the level of technical talent and technical creativity of lower secondary school children, aged from 11 to 15 years. The results of the research will be the base for making conclusions about the effect of gender and age of a student and the closing assessment at the class of technique and technology on the level of technical talent and technical creativity.

The following hypotheses were made:

- Hypothesis 1: Females will reach better result on the test of technical creativity; males will reach better result on the test of technical talent.

- Hypothesis 2: Technical creativity and technical talent are dependent on age; older students will reach better results on both tests.

- Hypothesis 3. Students with higher assessment at technique and technology will reach higher results on the tests of technical creativity and technical talent.

\section{Methodology of Research}

\section{General Research Characteristics}

Empirical research was held with an intention of upgrading the treatment of measuring of technical talent and technical creativity of students with the use of made paraphernalia. This is allowing verifiability and portability of findings also on other fields of education. 
Andrej ŠAFHALTER, Dragica PEŠAKOVIĆ. Technical talent and technical creativity in lower secondary school students

PROBLEMS

OF EDUCATION

IN THE $21^{\text {st }}$ CENTURY

Volume 65,2015

The intention of the research is to look into the condition of level of technical talent and technical creativity of students in lower secondary school, aged from 11 to 15 years. The study uses a method of causal non-experimental educational research.

\section{Sample of Research}

The research was based on the sample, which included 109 pupils of $6^{\text {th }}, 7^{\text {th }}, 8^{\text {th }}$ and $9^{\text {th }}$ grade, aged between 11 and 15 years. From the table 1 it can be seen that almost the same amount of females $(51.8 \%)$ and males $(48.2 \%)$ was included in the research. Tested students had closing assessment at technique and technology good, very good or excellent. The testing of students was done in the classroom at technique and technology.

The test of technical talent and technical creativity occurred with the help of teachers of technique and technology and a specialist from the field of didactics. The validity of instrument was ensured with this. The test was used twice before the research and the results were equal. The instrument was thought to be reliable. Objectivity was ensured like this, that a teacher did not influence execution of procedure, which a student was carrying out. Sensitivity was ensured with the inclusion of activity of a student on lower and higher taxonomic level.

\section{Instrument and Procedures}

Students were tested with the modeled test of technical talent and technical creativity. The test of technical talent consisted of tasks that were checking the correct thinking and the knowledge of technical devices, processes, the use of tools and machines and spatial ability. Already existent tests of verification of technical talent helped at composition e.g., test Introduction to Mechanical Aptitude (Pluta, Hunt \& Shartzer, n.d.), Mechanical Reasoning Test, Sample Mechanical Reasoning Test, Mechanical Reasoning: Practice Test 1 (Newton \& Bristoll, n.d.).

The test of technical creativity was made with the help of the Torrance test of creative thinking. The test is made from two drawings, in which a student shows different elements of his own abilities of technical expressing. The first task is presenting a word part, in which the student should write as many uses of the gear drives as possible. In the non-verbal part, a student must fill in an unfinished picture. Assigned time that a student had was limited, in our case on 45 minutes. All students were tested in suitable test conditions. All tests were valid and included in the analysis.

\section{Data Analysis}

Data were computationally treated with a program for statistical data processing of SPSS 20.0 on the level of descriptive and inferential statistics.

On the level of descriptive statistics were used next procedures:

- frequency distribution (f, f \%) of descriptive variables (gender, age and closing assessment at technique and technology),

- degree of middle values, metres of variation and metres of correlation.

Procedures which were used on the level of inferential statistics:

- t-test for independent samples of verification of differences within technical talent and technical creativities,

- the variance analysis for verification of differences within technical talent and technical creativity considering closing assessment at the subject of technique and technology. 


\section{Results of Research}

The results of the test and their interpretation are introduced below. In table 1 are offered the results of t-test for verification of differences of technical creativity and of technical talent considering the gender of a student. The research was checking if technical creativity and technical talent are dependent on the gender of a student.

Table 1. Outcome of t-test for independent samples of verification of differences of technical creativity and technical talent - considering the gender of a student.

\begin{tabular}{|c|c|c|c|c|c|c|}
\hline \multirow[t]{2}{*}{ Gender } & & \multirow[b]{2}{*}{$\mathrm{n}$} & \multirow[b]{2}{*}{$M$} & \multirow[b]{2}{*}{ SD } & \multicolumn{2}{|c|}{$\begin{array}{l}\text { Test for difference of } \\
\text { arithmetic means }\end{array}$} \\
\hline & & & & & $t$ & $p$ \\
\hline \multirow{2}{*}{ Creativity } & Male & 53 & 5.72 & 2.63 & \multirow{2}{*}{-1.06} & \multirow{2}{*}{0.29} \\
\hline & Female & 56 & 6.30 & 3.15 & & \\
\hline \multirow{2}{*}{ Talent } & Male & 53 & 14.89 & 3.23 & \multirow{2}{*}{0.77} & \multirow{2}{*}{0.44} \\
\hline & Female & 56 & 14.38 & 3.70 & & \\
\hline
\end{tabular}

Based on the collected results, the first hypothesis was rejected. It was assumed that females would get higher results than males on the test of technical creativity. In contrary, it was assumed that males would get better results than females on the test of technical talent. Predictions of the results were otherwise entitled, but they are not statistically ascertainable.

The research was also checking if the technical talent and technical creativity are dependent on the grade of a student, which is shown in table 2 .

Table 2. Outcome of the analysis of variances of verification of differences within technical talent and technical creativity - considering the grade of a student.

\begin{tabular}{|c|c|c|c|c|c|c|}
\hline \multirow[t]{2}{*}{ Grade } & & \multirow[b]{2}{*}{$\mathrm{n}$} & \multirow[b]{2}{*}{ M } & \multirow[b]{2}{*}{ SD } & \multicolumn{2}{|c|}{$\begin{array}{l}\text { Test of Homogeneity } \\
\text { of Variances }\end{array}$} \\
\hline & & & & & $F$ & $p$ \\
\hline & 6th & 16 & 4.25 & 1.88 & \multirow{4}{*}{3.38} & \multirow{4}{*}{0.02} \\
\hline \multirow[t]{4}{*}{ Creativity } & 7th & 55 & 6.69 & 3.04 & & \\
\hline & 8th & 18 & 6.11 & 3.39 & & \\
\hline & 9th & 20 & 5.50 & 2.12 & & \\
\hline & 6th & 16 & 12.13 & 3.18 & \multirow{4}{*}{6.48} & \multirow{4}{*}{0.00} \\
\hline \multirow[t]{3}{*}{ Talent } & 7th & 55 & 14.25 & 3.17 & & \\
\hline & 8th & 18 & 16.11 & 4.11 & & \\
\hline & 9th & 20 & 16.30 & 2.47 & & \\
\hline
\end{tabular}

The assumption about homogeneity of variances at technical creativity and technical talent is justified $(\mathrm{p}<0.05)$, because students from sixth grades (age 10 years) reached on average lower results than students from ninth grades (age 14 years).

The second hypothesis, which has claimed that technical creativity and technical talent are dependent on the age of a student, was confirmed. 
Andrej ŠAFHALTER, Dragica PEŠAKOVIĆ. Technical talent and technical creativity in lower secondary school students

PROBLEMS

OF EDUCATION

IN THE $21^{\text {st }}$ CENTURY Volume 65,2015

The results of technical creativity and technical talent considering closing assessment at technique and technology are presented in table 3. The next question in the research was if technical talent and technical creativity are dependent upon closing assessment at technique and technology.

Table 3. Outcome of the analysis of variances of verification of differences in technical creativity and technical talent considering closing assessment at technique and technology.

\begin{tabular}{|c|c|c|c|c|c|c|}
\hline \multicolumn{5}{|c|}{ Assessment } & \multicolumn{2}{|c|}{$\begin{array}{l}\text { Test of Homogeneity } \\
\text { of Variances }\end{array}$} \\
\hline & & $n$ & $M$ & SD & $\mathrm{F}$ & $p$ \\
\hline \multirow{4}{*}{ Creativity } & Good & 18 & 4.50 & 2.75 & \multirow{3}{*}{4.00} & \multirow{3}{*}{0.01} \\
\hline & Very good & 47 & 5.66 & 2.75 & & \\
\hline & Excellent & 44 & 7.02 & 2.83 & & \\
\hline & Good & 18 & 12.06 & 3.69 & \multirow{3}{*}{7.74} & \multirow{3}{*}{0.00} \\
\hline \multirow[t]{2}{*}{ Talent } & Very good & 47 & 14.19 & 3.10 & & \\
\hline & Excellent & 44 & 16.14 & 3.05 & & \\
\hline
\end{tabular}

The assumption about homogeneity of variances at technical creativity and technical talent $(\mathrm{p}<0.05)$ is justified, since the students with closing assessment well 3, on five-level marking scale, on average achieved lower results than the students with closing assessment excellent 5 . The third hypothesis, which claimed that technical creativity and technical talent depend upon closing assessment at technique and technology, was confirmed.

\section{Discussion}

It turned out that the students on the forwarded test of creativity had achieved mostly low rate of creativity, general and as well verbal and non-verbal, low originality and fluency, unexpressed elaboration and middle level of flexibility. Higher level of student's creativity than they expressed on the given test of creativity, was expected. Causes can be searched in the next facts:

- inspiration is very important for creative product, but it is hard to entice at students within situation which isn't favorable for expressing creativity,

- motivation is also a key meaning for expressing creativity, which was lower, because some students tasks seemed boring and inappropriate for their age.

Academic success depends also upon individual's creativity. Females expressed higher level of verbal and consequentially also general creativity, whereas on non-verbal part there weren't any differences considering gender. Creativity depends also upon the age of a student. Creativity is a complex occurrence and therefore, it is difficult to measure.

Numerous researches in the world are confirming this ( $\mathrm{Ai}, 1999)$. It was found out that the creativity of children is always smaller. Time that children spend with electronic devices and activities that aren't strengthening creative way of thinking is being listed as cause. The era of so called crisis of creativity has begun (Bronson, Merryman, 2011).

For continuation of schooling of technical directions and technical professions more males than females are deciding (Sorby, 2007), although on the field of talent, as we could find out, females are not falling behind. We can explain this also from the evolutionary point of view (Gardner, 2010), since males used to be hunters and they had to make suitable tools for hunting. As well, from the same point of view, males should had better spatial ability, although some 
authors (Titze, Heil \& Jansen, 2008; Šafhalter, Glodež, Bakračevič Vukman \& Aberšek, 2014) find out that differences among males and females don't exist. Right because of potential worse spatial ability (Sorby, 2007), females are deciding less for engineer's professions. The author has found out (Sorby, 2006; Sorby 2009) that this is the key meaning for success on the fields of engineer's graphics, as well as in education, especially mathematics and natural science. Profound influence on developing of talent has also the environment, in which an individual is developing in.

Experiences and age can also influence successful rescuing of tasks of technical talent, since the higher chance exists that students of $8^{\text {th }}$ and $9^{\text {th }}$ grade are already on the rate of formally logical (Labinowicz, in 2010) thinking considering Piaget's classification. The results also confirmed this, since students, aged 14 and 15 years, achieved better scores. Certain ability can be improved as well with individual activities, which is ascribed to environmental effect (Hebb, 1980, and Kolb \& Whishaw, 2014). At the subject of technique and technology there are activities that can influence on successful rescuing of the test of technical talent. Mentioned factors are probably true for technical creativity in smaller degree, which was also shown in the research.

\section{Conclusions}

Technical factors, which are complementary to each other, have a higher degree of integration. Within practice this means that with developing of any factor of creativity, we are indirectly developing and encouraging all others. Since students in the class are differently reacting to teacher's impulses and direction of technically creative part, a teacher must act at the practical realization of an educational process, so that he will alternately activate different factors of technical creativity at students. Only with that kind of work he can expect an increase of creativity as a whole.

It would be interesting to compare the results of this study, which are centered only on the area of Slovenia, with similar studies that have been made outside of its borders and to search out for eventual resemblances and differences.

Similar is true for technical talent, where the results of researches could be compared to the results, gained on marking scales for talent. With the help of that, the talent on certain area is identified.

Technical talent is being identified with the marking scale OLNAD07 that contains eight different claims, on which an assessor (a teacher) determines the individual student with assessments from 1 to 7 . Considering the results of this chart, it determines student as talented, if he achieves at least 49 points from 56 possible. It is desirable that at least two teachers, who teach him on this field, assess the same student, but that wasn't possible in the described research.

\section{References}

Ai, X. (1999). Creativity and academic achievement: An investigation of gender differences. Creativity Research Journal, 12 (4), 329-337.

Bezić, T., Boben, D., Juriševič, M., Nagy, M., Nolimal, F., Rostohar, G., ... Zorko, S. (2008). Ocenjevalne lestvice nadarjenosti učenca-izpopolnjena oblika 2007 (OLNAD07). [Marking scales of student's talent - improved version 2007]. Ljubljana: Zavod RS za šolstvo. Retrieved March 10, 2015, from http://bit.ly/17JHpQh

Bronson, P. Merryman, A. (2011). Nurture Shock: New thinking about children. New York: Twelve.

Claxton, G., Edwards, L., \& Scale-Contantinou, V. (2006). Cultivating creative mentalities: A framework for education. Thinking Skills and Creativity, 1 (1), 57-61. doi:10.1016/j.tsc.2005.11.001 
Andrej ŠAFHALTER, Dragica PEŠAKOVIĆ. Technical talent and technical creativity in lower secondary school students

PROBLEMS

OF EDUCATION

IN THE $21^{\text {st }}$ CENTURY Volume 65, 2015

80

Craft, A. (2006). Creativity in Schools. In Jackson, Oliver, Shaw \& Wisdom (Eds.), Developing Creativity in Higher Education: An Imaginative Curriculum (19-28). New York, London: Routledge.

Craft, A., Jeffrey, B. \& Leibling, M. (2001). Creativity in Education. London: Continuum International Publishing Group Ltd.

Fakin, M., Kocijančič, S., Hostnik, I., \& Florjančič, F. (2011). Program osnovna šola: tehnika in tehnologija, učni načrt, 2011. [Program lower secondary school: Technique and technology, curriculum]. Ljubljana: Ministrstvo za šolstvo in šport RS. Retrieved March 10, 2015, from http:// bit.ly/14tRxMq.

Gardner, H. (2010). Frames of mind: The theory of multiple intelligences. New York: Basic Books, A Member of the Perseus Books Group.

Guilford, J. P., \& Hoepfner, R. (1971). The analysis of intelligence. New York: McGraw-Hill.

Guilford, J. P. (1977). Fundamental statistics in psychology and education. New York: McGraw-Hill.

Jauševec, N. (1987). Spodbujanje otrokove ustvarjalnosti [Encouraging child's creativity]. Ljubljana: Državna založba Slovenije.

Jurman, B. (2004). Inteligentnost, ustvarjalnost, nadarjenost [Intelligence, creativity, talent]. Ljubljana: Center za psihologijo.

Kolb, B., \& Whishaw, I. Q. (2014). An introduction to brain and behavior. Fourth Edition. New York: Worth publishers.

Kvaščev, R. (1976). Psihologija stvaralaštva [Psychology of creativity]. Beograd: Beogradsko izdavačko grafički zavod.

Labinowicz, E. (2010). Izvirni Piaget [Original Piaget]. Ljubljana: DZS

Leach, J. (2001). A hundred possibilities: Creativity, community and ICT. In Craft, Jeffrey \& Leibling (Eds.), Creativity in Education (175-192). London: Continuum International Publishing Group Ltd.

Lowenfeld, V., \& Brittain, W. L. (1964). Creative and mental growth. New York: The MacMillian Company.

Newton, P., \& Bristoll, H. (n.d.) Mechanical reasoning: Practice Test 1. Retrieved October 13, 2014 from http://bit.ly/1CcGDrW.

Pečjak, V. (1987). Misliti, delati, živeti ustvarjalno [Think, work, live creative]. Ljubljana: DZS.

Pluta, P. E., Hunt, A. C., \& Shartzer, M. C. (n.d.). Introduction to mechanical aptitude. Los Angeles: Department of Human Resources. Retrieved October 13, 2014 from http://bit.ly/1BChmFH.

Pregl, T. (2009). Vzgojno-izobraževalno delo z nadarjenimi učenci v osnovnih šolah štajerske regije (Diplomsko delo). [Educational work with talented students in lower secondary schools of Stryria region (Diploma work)]. Retrieved March 10, 2015 from http://bit.ly/1Eb9pFT.

Supek, R. (1987). Djete i kreativnost [Child and creativity]. Zagreb: Globus.

Šafhalter, A., Glodež, S., Bakračević Vukman, K., \& Aberšek, B. (2014). Developing spatial ability using 3D modeling in lower secondary school. Problems of Education in the 21st Century, 61, 113-120.

Sorby, S. A. (2006). Developing 3D spatial skills for K-12 students. Engineering Design Graphics Journal, 70 (3), 1-11.

Sorby, S. A. (2007). Developing 3D spatial skills for engineering students. Australasian Journal of Engineering Education, 13 (1), 1-11.

Sorby, S. A. (2009). Educational research in developing 3-D spatial skills for engineering students. International Journal of Science Education, 31 (3), 459-480.

Titze, C., Heil, M., Jansen, P. (2008). Gender Differences in the Mental Rotations Test (MRT) are not due to task complexity. Journal of Individual Differences, 29 (3), 130-133.

Torrance, P. (1981). Kreativnost. Pedagogija. Časopis saveza pedagoških društava Jugoslavije, (1) [Creativity. Pedagogy. Newspaper union of educational societies of Yugoslavia].

Žagar, D. (1992). Ustvarjalnost [Creativity]. Ljubljana: Zavod Republike Slovenije za šolstvo. 
Andrej ŠAFHALTER, Dragica PEŠAKOVIĆ. Technical talent and technical creativity in lower secondary school students

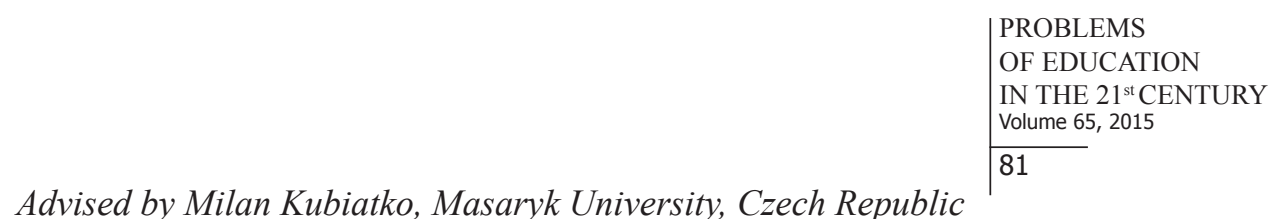

Received: May 09, 2015

Accepted: June 18, 2015

\begin{tabular}{|ll|} 
Andrej Šafhalter & $\begin{array}{l}\text { Professor, Primary School Anice Černejeve Makole, Makole 24, } 2321 \text { Makole, } \\
\text { Slovenia. } \\
\text { E-mail: andrej.safhalter@os-makole.si } \\
\text { Website: http://www.os-makole.si }\end{array}$ \\
\hline Dragica Pešaković & $\begin{array}{l}\text { PhD, Professor, Lower Secondary School Destrnik-Trnovska vas, Janežovski } \\
\text { Vrh 45, 2253 Destrnik, Slovenia. } \\
\text { E-mail: dragica.pesakovic@guest.arnes.si } \\
\text { Website: http://www.os-destrnik.si/ }\end{array}$
\end{tabular}

